\title{
Ameliorative Effect of Adjunct Therapy of Metformin with Atorvastatin on Streptozotocin-induced Diabetes Mellitus in Rats
}

\author{
Authors \\ B. K. Singh, A. Singh, V. Kumar \\ Affiliation \\ Department of Pharmacology, KIET School of Pharmacy, Ghaziabad, India
}

\author{
Key words \\ - diabetes mellitus \\ - metformin \\ atorvastatin \\ - lipid profiles \\ oxidative stress
}

received $\quad 07.02 .2015$

accepted 17.03.2015

Bibliography

DOI http://dx.doi.org/

$10.1055 / \mathrm{s}-0035-1548822$

Published online:

April 8, 2015

Drug Res 2016;

66: 28-32

(c) Georg Thieme Verlag KG

Stuttgart · New York

ISSN 2194-9379

Correspondence

Dr. V. Kumar, Associate

Professor

Head Department of

Pharmacology

KIET School of Pharmacy

Ghaziabad-Meerut Road

201206, Ghaziabad (UP)

India

Tel.: + 91/971/1060 878

Fax: + 91/120/2675 091

vinaykumarpatel@gmail.com

\section{Abstract}

$\nabla$

Metformin has been used for the treatment of diabetes, whereas atorvastatin reduces the incidence of atherosclerosis and ischemic heart disease. Therefore, combined treatment with meformin plus atorvastatin may be beneficial in diabetic patients associated with cardiac disease. The present study was designed to evaluate the combination therapy of metformin and atorvastatin on streptozotocin-induced diabetes mellitus in rats. Blood pressure, serum insulin, glucose, lipid profiles and antioxidant enzymes in pancreatic tissues were measured. Histopathological examination of pancreatic tissues was performed. Streptozotocin treated rats showed significant decrease in body weight and body mass index. Streptozo-

\section{Introduction}

$\nabla$

Diabetes and its complications are a major health problem in modern societies. Diabetes mellitus (DM) comprises abnormalities of insulin action including insulin deficiency and insulin resistance. It is characterized by chronic hyperglyceamia with disturbances of carbohydrate, fat and protein metabolism resulting from defects in insulin secretion, insulin action or both [1]. It is commonly associated with endothelial dysfunction [2]. Various studies have reported that increased production of reactive oxygen species (ROS) resulting from metabolism of excessive glucose and free fatty acid as well as decreased expression of antioxidant enzymes have been responsible for deterioration of pancreatic $\beta$-cells [3]. Hyperglyceamia also enhances the oxidative modification of low density lipoprotein (LDL) which induces production of cellular adhesion molecules (CAM) and increase monocyte adhesion [4]. tocin-treated rats showed a significant increase in the levels of blood pressure, serum glucose, triglycerides, total cholesterol and thiobarbituric acid reactive substance as well as a significant decrease in the levels of serum insulin, high density lipoprotein and reduced glutathione in pancreatic tissues. Administration of metformin plus atorvastatin for a period of 14 days significantly improved these biochemical parameters near to normal. The protective effect of metformin plus atorvaststin against streptozotocin-induced diabetes was further confirmed by histopathological examination. The results of present study suggest that metformin plus atorvastatin possess antioxidant activity and has a significant protective effect against streptozotocin-induced diabetes mellitus.

Streptozotocin (STZ) a naturally occurring broad spectrum antibiotic and is toxic to the insulin producing pancreatic $\beta$-cells. Oxidative stress may be responsible for deterioration of pancreatic $\beta$-cells. Thus, oxidative stress play a key role for the development of DM. Studies also reported that administration of STZ led to increase production of ROS resulting from metabolism of excessive glucose and free fatty acids, and decreased expression of antioxidant enzymes. Thus, STZ induced oxidative stress may play a major role for development of DM $[2,3]$.

Metformin, a biguanide, is the most widely prescribed drug for the treatment of hyperglycaemia in type II diabetics $[5,6]$. It blocks hepatic gluconeogensis and increases hepatic insulin sensitivity as well as to a lesser extent insulin mediated glucose uptake in fat and muscle tissue [7]. Metformin has a potent antioxidant and anti-inflammatory properties [8]. In recent years, study reported that metformin exerts several pleiotropic effects including beneficial changes in blood rheology, serum lipid profile and putative 
anti-ischemic effects [9]. Atorvastatin has been reported to reduce the incidence of atherosclerosis, ischemic heart disease associated with diabetes [10] and nephrotoxicity [11].

Since the combined effect of metformin and atorvastatin has not been studied on diabetic rats, thus, the present study aimed to investigate the combined effect of metformin and atorvastatin on STZ-induced diabetes mellitus in rats.

\section{Materials and Methods}

$\nabla$

\section{Drugs and chemicals}

Metformin and atorvastatin calcium were obtained as a gift samples from Alkem Research Center, Navi Mumbai, India. STZ was purchased from Sigma Aldrich (St. Louis, LO, USA). All other chemicals used in this study were of analytical grade.

\section{Animals}

Male Wistar rats weighing 180-250g, were procured from the Animal House facility, KIET School of Pharmacy (Ghaziabad, India). The animals were kept in polypropylene cages under standard laboratory conditions ( $12 \mathrm{~h}$ light and $12 \mathrm{~h}$ dark cycle), and had a free access to commercial pellet diet (Pranav Agro Industries, New Delhi) and water ad libitum. The animal house temperature was maintained at $25 \pm 2{ }^{\circ} \mathrm{C}$. The protocol was approved by Institutional Animal Ethics Committee of KIET School of Pharmacy (Registration number 1099/07/CPCSEA).

\section{Experimental design}

After acclimatization, all rats were treated with STZ $(60 \mathrm{mg} / \mathrm{kg}$ in $0.1 \mathrm{M}$ citrate buffer, $\mathrm{pH} 4.5$, intraperitoneally, single dose) except rats of Group I (normal control group). Rats having hyperglycemia (fasting blood glucose level $\geq 200 \mathrm{mg} / \mathrm{dl}$ ) after $48 \mathrm{~h}$ of single injection of STZ were included in this study and divided in following groups of 8 animals: Group I (control group) - rats treated with citrate buffer $(0.1 \mathrm{M})$ solution; Group II (diabetic group) - Animals received streptozotocin $(60 \mathrm{mg} /$ $\mathrm{kg}$, intraperitoneally, single dose); Group III (Streptozotocin+metformin): Animals were treated with metformin $(200 \mathrm{mg} / \mathrm{kg} /$ day $)$ after $48 \mathrm{~h}$ of streptozotocin administration, for 14 days. Group IV and V (Streptozotocin + metformin + atorvastatin): Animals were treated with metformin (100 and $200 \mathrm{mg} /$ $\mathrm{kg}$, respectively) and atorvastatin (20 and $40 \mathrm{mg} / \mathrm{kg}$, respectively) after $48 \mathrm{~h}$ of streptozotocin administration, for 14 days. Body mass index was calculated.

\section{Measurement of hemodynamic parameters}

Hemodynamic parameters (systolic, diastolic, mean arterial blood pressure, and heart rate) were measured by non-invasive blood pressure recorder using rat tail-cuff method (AD Instruments, Australia) on the $15^{\text {th }}$ day.

\section{Measurement of biochemical parameters in serum}

Blood was collected from the retro-orbital plexus of overnight fasted rats using microcapillary tubes on $15^{\text {th }}$ day. Serum was separated by centrifugation ( $4000 \mathrm{rpm}$ for $10 \mathrm{~min}$ ) and transferred to micro centrifuge tubes. Serum glucose, total cholesterol (TC), triglycerides (TGs) were measured using commercial kits from Span Diagnostics Ltd, Surat, Gujarat, India and highdensity lipoprotein-cholesterol (HDL-C) from Reckon Diagnostics Pvt. Ltd., Baroda, Gujarat, India. The concentration of serum insulin was measured using rat insulin ELISA kit (Alpco Diagnostics, Salem, USA).

\section{Biochemical estimations in pancreatic tissue}

Immediately after the sacrifice, the pancreas was excised out, washed in ice cold normal saline and weigh. Subsequently, the weighed quantity of pancreatic tissue from each group homogenized $\mathrm{w} / \mathrm{v}$ in ice-chilled phosphate buffer $(50 \mathrm{mM}, \mathrm{pH} 7.4)$ and centrifuge at $10000 \mathrm{~g}$ for $20 \mathrm{~min}$. A clear supernatant was used for assaying different biochemical parameter according to the procedure. Lipid peroxidation was determined with spectrophotometric measurement of amount of malondialdehyde equivalents with thiobarbituric acid and was expressed as thiobarbituric acid-reactive substances ( $\mathrm{nmol}$ malondialdehyde) mg protein) according to method of Ohkawa et al. [12]. Glutathione was measured according to Ellman, [13] method.

\section{Histopathological examination}

Pancreas tissue samples were fixed in $10 \%$ formalin buffered solution, cut into $5 \mu \mathrm{m}$ sections and stained with haematoxylin $\&$ eosin. The sections were studied for pathological changes.

\section{Statistical analysis}

The results are expressed as mean \pm SEM. Comparison between the treatment groups and control groups were performed by analysis of variance (ANOVA) followed by Dunnett's t-test. The criteria for statistical significance was $\mathrm{p}<0.05$.

\section{Results}

$\nabla$

Assessment of mortality, body weight and body mass index

In the present study, $10 \%$ mortality was observed in STZ treated group only. No mortality was found in other groups. Body weight and body mass index were significantly $(\mathrm{P}<0.001)$ decreased in STZ treated rats compared to control group. Treatment with metformin along with atorvastatin significantly $(\mathrm{P}<0.05$ and $\mathrm{P}<0.01$ ) increased the body weight and body mass index as compared to STZ group ( $\odot$ Table 1 ).

\section{Assessment of hemodynamic parameters}

There was significant $(\mathrm{P}<0.05)$ increase in hemodynamic parameters (systolic, diastolic, mean BP and heart rate) in Group II i.e., diabetic control group as compared to the normal control

Table 1 Influence of metformin and atorvastatin on streptozotocin-induced changes in body weight, body mass index and mortality.

\begin{tabular}{|c|c|c|c|}
\hline Groups & BW (gm) & $\mathrm{BMI}\left(\mathrm{g} / \mathrm{cm}^{2}\right)$ & \% Mortality \\
\hline Normal Control & $253.75 \pm 3.24$ & $0.67 \pm 0.01$ & 0 \\
\hline STZ Control & $142.50 \pm 3.90^{a}$ & $0.42 \pm 0.021^{\mathrm{a}}$ & 10 \\
\hline STZ + MET 200 & $191.25 \pm 5.85^{b}$ & $0.54 \pm 0.022^{b}$ & 0 \\
\hline STZ + MET100 + ATV20 & $193 \pm 6.39^{b}$ & $0.55 \pm 0.033^{b}$ & 0 \\
\hline STZ + MET100 + ATV40 & $201.25 \pm 7.58^{c}$ & $0.58 \pm 0.042^{c}$ & 0 \\
\hline \multicolumn{4}{|c|}{$\begin{array}{l}\text { BW indicate body weight; BMI, body mass index; STZ, streptozotocin }(60 \mathrm{mg} / \mathrm{kg}) \text {; } \\
\text { STZ + MET: streptozotocin }(60 \mathrm{mg} / \mathrm{kg})+\text { metformin }(200 \mathrm{mg} / \mathrm{kg}) \text {; STZ + MET100 + ATV } \\
\text { 20: streptozotocin }(60 \mathrm{mg} / \mathrm{kg})+\text { metformin }(100 \mathrm{mg} / \mathrm{kg})+\text { atorvastatin }(20 \mathrm{mg} / \mathrm{kg}) \text {; } \\
\text { STZ + MET200 + ATV40: streptozotocin }(60 \mathrm{mg} / \mathrm{kg})+\text { metformin }(200 \mathrm{mg} / \mathrm{kg})+\text { atorv- } \\
\text { astatin }(40 \mathrm{mg} / \mathrm{kg})\end{array}$} \\
\hline $\begin{array}{l}\text { Data are expressed as mea } \\
{ }^{a} \mathrm{P}<0.001 \text { vs. Normal Cont } \\
{ }^{\mathrm{b}} \mathrm{p}<0.05 \text { and }{ }^{\mathrm{C}} \mathrm{p}<0.01 \text { vs. }\end{array}$ & \pm standard error of & ean & \\
\hline
\end{tabular}




\begin{tabular}{|lllll|} 
Groups & Heart Rate (BPM) & Systolic BP $(\mathbf{m m H g})$ & Diastolic BP $(\mathbf{m m ~ H g})$ & Mean BP $(\mathbf{m m H g})$ \\
\hline Normal Control & $392.29 \pm 6.5$ & $114.56 \pm 2.96$ & $99.96 \pm 1.58$ & $107.26 \pm 2.39$ \\
\hline STZ Control & $568.70 \pm 12.34^{\mathrm{a}}$ & $169.07 \pm 4.86^{\mathrm{a}}$ & $126.95 \pm 2.90^{\mathrm{a}}$ & $147.51 \pm 3.17^{\mathrm{a}}$ \\
\hline STZ+MET 200 & $472.09 \pm 8.07^{\mathrm{b}}$ & $145.09 \pm 4.25^{\mathrm{b}}$ & $115.20 \pm 2.71^{\mathrm{b}}$ & $129.45 \pm 2.36^{\mathrm{b}}$ \\
STZ+MET100+ATV20 & $441.09 \pm 7.53^{\mathrm{b}}$ & $133.02 \pm 3.16^{\mathrm{b}}$ & $106.48 \pm 2.22^{\mathrm{b}}$ & $119.25 \pm 2.32^{\mathrm{b}}$ \\
\hline STZ+MET100+ATV40 & $414.21 \pm 5.15^{\mathrm{c}}$ & $122.98 \pm 3.13^{\mathrm{c}}$ & $102.95 \pm 2.13^{\mathrm{c}}$ & $111.47 \pm 2.18^{\mathrm{c}}$ \\
\hline
\end{tabular}

Table 2 Influence of metformin and atorvastatin on systolic, diastolic, mean BP and heart rate of Wistar rats.

Table 3 Influence of metformin and atorvastatin on serum Total cholesterol, triglycerides, HDL-C, glucose and insulin levels of Wistar rats.

\begin{tabular}{|lccccc}
\hline Groups & Total Cholesterol (mg/dl) & Triglycerides (mg/dl) & HDL-C (mg/dl) & Glucose (mg/dl) & Insulin (ng/ml) \\
\hline Normal Control & $148.69 \pm 2.00^{a}$ & $138.72 \pm 2.19^{\mathrm{m}}$ & $45.62 \pm 1.01$ & $97.14 \pm 2.16$ & $0.268 \pm 0.02$ \\
\hline STZ Control & $257.06 \pm 4.74^{\mathrm{a}}$ & $206 \pm 5.63^{\mathrm{a}}$ & $24.28 \pm 0.94^{\mathrm{a}}$ & $328.21 \pm 4.65^{\mathrm{a}}$ & $0.110 \pm 0.35^{\mathrm{a}}$ \\
\hline STZ + MET200 & $198.29 \pm 2.71^{\mathrm{b}}$ & $197.59 \pm 2.42$ & $36.63 \pm 0.64^{\mathrm{b}}$ & $156.66 \pm 1.24^{\mathrm{c}}$ & $0.156 \pm 0.02^{\mathrm{b}}$ \\
\hline STZ+MET100+ATV20 & $175.08 \pm 3.30^{\mathrm{c}}$ & $153.62 \pm 3.43^{\mathrm{c}}$ & $40.46 \pm 0.79^{\mathrm{b}}$ & $128.25 \pm 2.32^{\mathrm{c}}$ & $0.188 \pm 0.02^{\mathrm{c}}$ \\
\hline STZ+MET100+ATV40 & $163.29 \pm 2.71^{\mathrm{c}}$ & $144.59 \pm 2.42^{\mathrm{c}}$ & $42.86 \pm 0.64^{\mathrm{c}}$ & $116.47 \pm 2.18^{\mathrm{c}}$ & $0.196 \pm 0.01^{\mathrm{c}}$ \\
\hline
\end{tabular}

Data are expressed as mean \pm standard error of mean; ${ }^{a} \mathrm{P}<0.001$ vs. Normal Control, ${ }^{b} \mathrm{p}<0.05$ and ${ }^{\mathrm{c}} \mathrm{p}<0.01 \mathrm{vs}$. STZ Control

group (i.e., Group I) while the treatment with metformin along with atorvastatin significantly $(\mathrm{P}<0.05$ and $\mathrm{P}<0.01)$ reduced the blood pressure and heart rate in dose dependent manner as compared to the Group II ( $\odot$ Table 2 ).

\section{Assessment of serum glucose}

A significant $(\mathrm{P}<0.001)$ rise in the serum glucose level was observed in STZ treated rats. While the treatment with metformin plus atorvastatin significantly $(\mathrm{P}<0.001)$ decreased serum glucose as compared to STZ treated rats in a dose dependent manner ( $\odot$ Table 3).

\section{Assessment of serum high density lipoprotein-}

\section{cholesterol (HDL-C) and insulin}

There was a significant $(\mathrm{P}<0.001)$ decrease in the serum HDL-C and insulin levels in STZ group compared to control group. Metformin and atorvastatin treatment significantly $(\mathrm{P}<0.05$ and $\mathrm{P}<0.01$ ) increased the serum HDL-C and insulin levels in dose dependent manner ( $\odot$ Table 3).

Assessment of serum total cholesterol and triglycerides Compared to control group, serum total cholesterol (TC) and triglycerides (TGs) level were significantly $(\mathrm{P}<0.01)$ increased in STZ treated rats. Treatment of metformin and atorvastatin significantly $(\mathrm{P}<0.05$ and $\mathrm{P}<0.01)$ decreased the TC and TGs level (० Table 3).

\section{Assessment of myocardial TBARS and antioxidant enzymes}

The thiobarbituric acid reactive substance (TBARS) level was significantly $(P<0.001)$ increased in STZ treated rats. TBARS level was significantly $(\mathrm{P}<0.01$ and $\mathrm{P}<0.001)$ decreased on treatment with metformin and atorvastatin.

STZ treated group showed a significant $(\mathrm{P}<0.001)$ decreased in the level of reduced glutathione (GSH) as compared to normal control group. Treatment with metformin and atorvastatin the reduced GSH level was significantly $(\mathrm{P}<0.01$ and $\mathrm{P}<0.001)$ increased in dose dependant manner ( $\odot$ Table 4$)$.

\section{Histopathological analysis}

Histopathological examination of the pancreatic tissue of normal control animals showed clear integrity of pancreatic cell membrane ( $\bullet$ Fig. 1a). No inflammatory cell infiltration was observed. STZ treated pancreatic tissue showed disorientation of
Table 4 Influence of metformin and atorvastatin on lipid peroxides (TBARS) and reduced glutathione (GSH) levels in pancreatic tissue of Wistar rats.

$\begin{array}{lll}\text { Groups } & \begin{array}{l}\text { TBARS }(\mathbf{n m o l} \\ \text { MDA/mg protein) }\end{array} & \begin{array}{l}\text { GSH }(\mu \mathrm{mol} / \mathbf{m g} \\ \text { protein) }\end{array} \\ \text { Normal Control Group } & 0.64 \pm 0.13 & 1.014 \pm 0.06 \\ \text { STZ Control Group } & 3.94 \pm 0.26^{\mathrm{a}} & 0.365 \pm 0.06^{\mathrm{a}} \\ \text { STZ + MET 200 } & 2.48 \pm 0.18^{\mathrm{b}} & 0.686 \pm 0.07^{\mathrm{b}} \\ \text { STZ+MET100+ATV20 } & 1.96 \pm 0.33^{\mathrm{b}} & 0.816 \pm 0.08^{\mathrm{b}} \\ \text { STZ+MET100+ATV40 } & 1.24 \pm 0.12^{\mathrm{c}} & 0.952 \pm 0.08^{\mathrm{c}}\end{array}$

Data are expressed as mean \pm standard error of mean; ${ }^{\mathrm{a}} \mathrm{P}<0.001 \mathrm{vs}$. Normal Control, ${ }^{b} p<0.05$ and ${ }^{c} p<0.01$ vs. STZ Control

muscle fibers, widespread myocardial structure with moderate infiltration of lymphocytes and macrophages ( 0 Fig. 1b) as compared to control. Treatment with metformin (100 and $200 \mathrm{mg} /$ $\mathrm{kg}$, respectively) plus atorvastatin $(20$ and $40 \mathrm{mg} / \mathrm{kg}$, respectively) showed marked improvement in the disorientation of muscle fibers, subendocardial necrosis and reduction in the inflammatory cells ( $\bullet$ Fig. 1c-e).

\section{Discussion}

$\nabla$

Diabetes is increasing at an alarming rate worldwide, which mainly be attributed to the sedentary life style and calorie-rich diet. Oxidative stress and alteration in lipid profile is often associated with diabetes. In the present study, the combined effect of metformin and atorvaststin attenuated blood pressure, heart rate, serum glucose levels, lipid profile and lipid peroxidation as well as augment of serum insulin and antioxidant activities.

In the present study, there was a significant decrease in body weight and BMI in STZ treated rats which were markedly increased on treatment with metformin and atorvastatin combination. Alterations in body weight and BMI in STZ treated rats could be due to consecutive loss of protein [14].

In diabetes, hyperglycemia is associated with disturbances of carbohydrate, fat and protein metabolism resulting from defects in insulin secretion, insulin action or both. There was significant $(\mathrm{P}<0.001)$ rise in the serum glucose level and decrease in serum insulin levels in STZ treated rats. Treatment with metformin and atorvastatin significantly $(\mathrm{P}<0.001)$ altered the serum insulin and glucose levels. Such effect may be due to decrease in the rate 


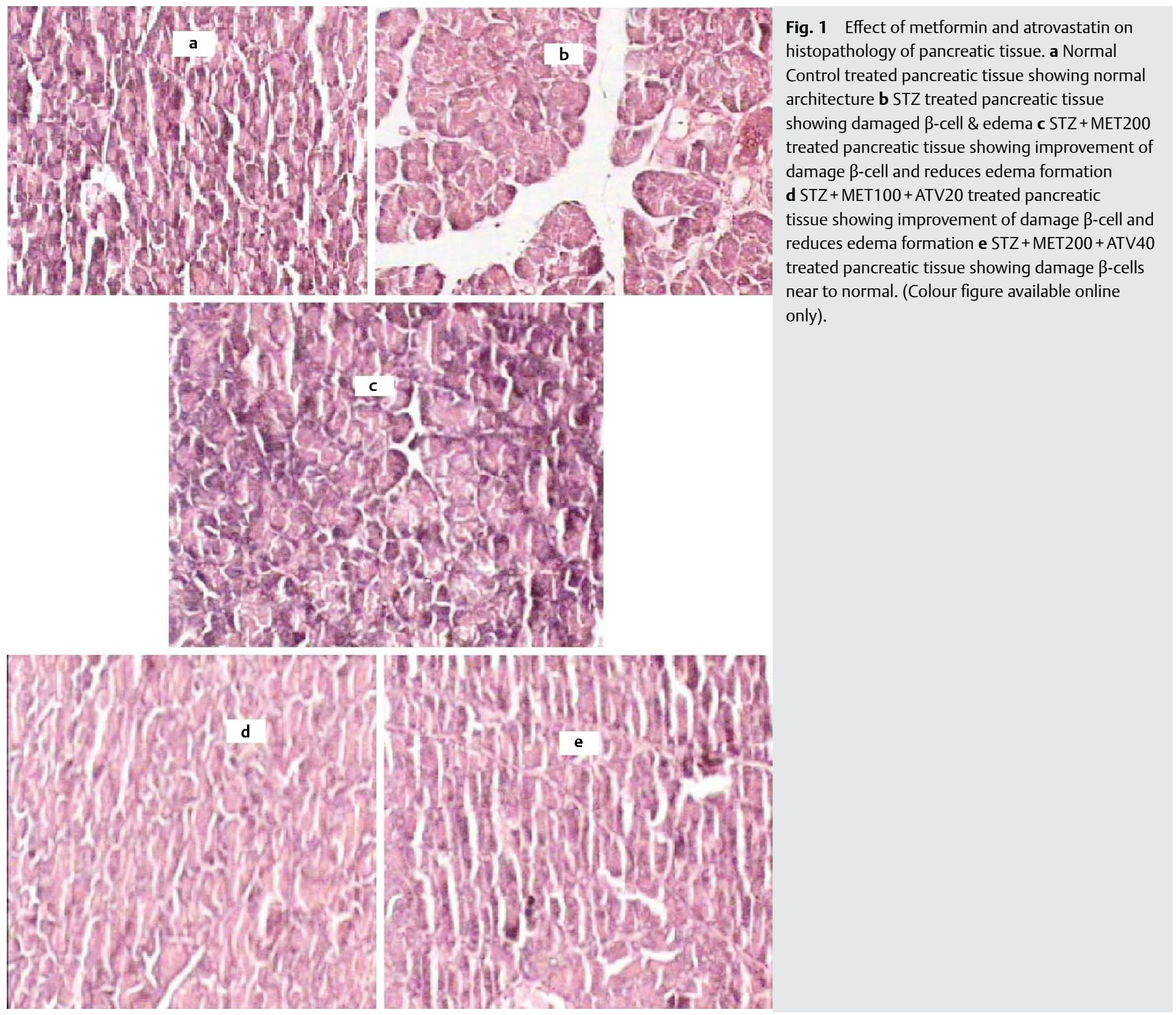

of intestinal glucose absorption or an increase in peripheral glucose utilization [15].

Hyperglycemia is also accompanied with dyslipidemia [16] which causes increased lipolysis in adipose tissues and increased entry of free fatty acids (FFA) to the liver [2,3]. Increased FFA and insulin independent glucose uptake in the liver is reported to stimulate triglyceride (TG) synthesis [17] that tends to reduce protein content of lipoproteins such as LDL and increases the TG content [18]. Dyslipidemia is an impending atherogenic risk factor in diabetes [18]. In the present study, STZ significantly increased serum total cholesterol (TC) and TG levels as well as significantly decreased serum HDL-C levels which were aliened with previous studies [19]. Administration of combined metformin and atorvastatin significantly attenuated serum TC and TG as well as significantly augment serum HDL-C levels. These finding demonstrated that combination of these drugs ameliorate dyslipidemia associated with diabetes.

Lipid peroxidation is an indication of the severity of STZ-induced diabetes. The increased levels of TBARS may contribute to increased generation of free radicals and/or decreased activities of antioxidant enzymes [20]. The results of the present study showed that combined treatment with metformin and atorvastatin significantly decreased STZ-induced elevation of TBARS level probably due to restoration of antioxidant enzymes that neutralized and/or scavenged the free radicals.

Hyperglycemia is a main cause for elevated free radical levels, followed by production of ROS, which can lead to altered antioxidant defense, insulin resistance and further impair glucose metabolism in biological system [21]. The antioxidant enzymes such as GSH, SOD and CAT are regarded as the first line of the antioxidant defense system against ROS generated during oxidative stress. In the present study, STZ treated rat's significantly decreased GSH level which goes fine with previous study [22]. Treatment with both metformin and atorvastatin augment GSH level, suggesting that it could boost the cellular antioxidative defense against oxidative stress. Atorvastatin possesses significant antioxidant and antihyperlipidemic activity due to reduction of lipid peroxidation. Therefore, treatment with both metformin and atorvastatin could be useful intervention to the diabetic patients.

\section{Conclusion}

$\nabla$

The present study provides experimental evidence that combination of metformin and atorvastatin has a potent pleiotropic 
effects including beneficial antioxidant activity, changes in blood rheology, serum lipid profile and putative anti-ischemic effects. Hence the combination therapy of metformin and atorvastatin could be useful intervention for the treatment of STZinduced diabetes mellitus in rats.

\section{Conflict of Interest}

$\nabla$

Authors have no conflict of interest.

\section{References}

1 WHO. Definition diagnosis and classification of diabetes mellitus and its complications. World Health Organization Department of Noncommunicable Disease Surveillance. 1999; (http://whglibdoc.who. int/hg/1999/WHO-NCD-NCS-99.2pdf) 60 p. Retrieved on 7/6/2012

2 Sharma S, Singh M, Sharma PL. Beneficial effect of insulin in hyperhomocysteinemia and diabetes mellitus-induced vascular endothelium dysfunction: role of phosphoinositide dependent kinase and protein kinase B. Molecular and cellular Biochemistry 2011; 348: 21-32

3 Farah $R$, Shurtz-Swirski R, Lapin $O$. Intensification of oxidative stress and inflammation in type 2 diabetes despite antihyperglycemic treatment. Cardiovascular Diabetologia 2008; 7: 1-8

4 Linthout SV, Riad A, Dhayat $N$ et al. Anti-inflammatory effect of atorvastatin improves left ventricular function in experimental diabetic cardiomyopathy. Diabetologia 2007; 50: 1977-1986

5 Adler AI, Shaw EJ, Stokes T et al. Newer agents for blood glucose control in type 2 diabetes: summary of NICE guidance. BMJ (Clinical research ed) 2009; 338: 1668

6 Nathan DM, Buse JB, Davidson MB et al. Medical management of hyperglycemia in type 2 diabetes: a consensus algorithm for the initiation and adjustment of therapy: a consensus statement of the American Diabetes Association and the European Association for the Study of Diabetes. Diabetes Care 2009; 32: 193-203

7 Stafford JM, Elasy T. Treatment update thiazolidinediones in combination with metformin for the treatment of type 2 diabetes. Journal of Vascular Health and Risk Management 2007; 3: 503-510

8 Dandona P, Aljada A, Ghanim H et al. Increased Plasma Concentration of Macrophage Migration Inhibitory Factor (MIF) and MIF mRNA in Mononuclear Cells in the Obese and the Suppressive Action of Metformin. Journal of Clinical Endocrinology and Metabolism 2004; 89: 5043-5047

9 Anfossi G, Russ I, Bonomo $K$ et al. The cardiovascular effect of metformin: further reasons to consider an old drug a cornerstone in the therapy of type 2 diabetes mellitus. Current Vascular Pharmacology 2010; 8: 327-337
10 Srinivas M, Annapurna A, Reddy YN. Anti-atherosclerotic effect of atorvastatin and clopidogrel alone and in combination in rats. Indian Journal of Experimental Biology 2008; 46: 698-703

11 Mehany HA, Abo-youssef AM, Ahmed LA et al. Protective effect of vitamin $\mathrm{E}$ and atorvastatin against potassium dichromate - induced nephrotoxicity in rats. Journal of Basic and Applied Sciences 2013; 2: $96-102$

12 Okhawa H, Ohishi $N$, Yagi K. Assay for lipid peroxides in animal tissues by thiobarbituric acid reaction. Analytical Biochemistry 1979; 95: 351-358

13 Ellman GL. Tissue sulfhydryl groups. Arch Biochem Biophys 1959; 82: 70-77

14 Kianifard D, Sadrkhanlou R, Hasanzadeh S. The histological, histomorphometrical and histochemical changes of testicular tissue in metformin treated and untreated streptozotocin - induced adult diabetic rats. Vet Res Forum 2011; 2: 13-24

15 Juarez-Rojop IE, Díaz-Zagoya JC, Ble-Castilo JL et al. Hypoglycemic effect of Carica papaya leaves in streptozotocin-induced diabetic rats. BMC Complementary and Alternative Medicine 2012; 12: 1-11

16 Sharma SB, Nasir A, Prabhu KM et al. Hypoglycaemic and hypolipidemic effect of ethanolic extract of seeds of Eugenia jambolana in alloxan-induced diabetic rabbits. Journal of Ethnopharmacology 2003; 85: 201-206

17 Zhang Q Wang GJ. Application of GC/MSbased metabonomic proling in studying the lipid-regulating effects of Ginkgo biloba extract on diet-induced hyperlipidemia in rats. Acta Pharmacologica Sinica 2009; 30: 1674-1687

18 De Sereday MS, Gonzalez C, Giorgini D et al. Prevalence of diabetes, obesity, hypertension and hyperlipidemia in the central area of Argentina. Diabetes and Metabolism 2004; 30: 335-339

19 Wang HJ, Jin YX, Shen Wet al. Low dose streptozotocin (STZ) combined with high energy intake can effectively induce type 2 diabetes through altering the related gene expression. Asia Pacific Journal of Clinical Nutrition 2007; 16: 412-417

20 Tripathi UN, Chandra D. The plant extracts of Momordica charantia and Trigonella foenum graecum have antioxidant and anti-hyperglycemic properties for cardiac tissue during diabetes mellitus. Oxidative Medicine and Cellular Longevity 2009; 2: 290-296

21 Ramesh B, Saralakumari D. Antihyperglycemic, hypolipidemic and antioxidant activities of ethanolic extract of Commiphora mukul gum resin in fructose fed male Wistar rats. Journal of Physiology and Biochemistry 2012; 68: 573-582

22 Robertson RP, Tanaka Y, Takahashi $H$ et al. Prevention of oxidative stress by adenoviral overexpression of glutathione-related enzymes in pancreatic islets. Annals of the New York Academy of Sciences 2005; 1043: $513-520$ 